\title{
VERIFICATION RESULTS FOR THE \\ NON-REAL PROPERTY RADIOLOGICAL RELEASE PROGRAM AT THE WEST VALLEY DEMONSTRATION PROJECT ASHFORD, NEW YORK
}

\author{
Prepared by
}

M. A. Buchholz

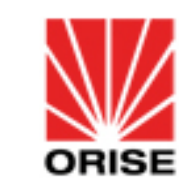

DOE CONTRACT NO. DE-AC05-06OR23100

Prepared for the

U.S. Department of Energy

\section{LETTER REPORT}

\section{APRIL 2009}

Approved for public release; further dissemination unlimited. 


\section{VERIFICATION RESULTS FOR THE NON-REAL PROPERTY RADIOLOGICAL RELEASE PROGRAM AT THE WEST VALLEY DEMONSTRATION PROJECT, ASHFORD, NEW YORK}

\section{INTRODUCTION}

In 1961, the state of New York acquired 3,345 acres of land in the town of Ashford, New York, near West Valley, for the Western New York Nuclear Service Center (WNYNSC). The next year Davison Chemical Company established Nuclear Fuels Services, Inc. (NFS) as a reprocessing company, and leased the WNYNSC. NFS developed 200 acres of the land and operated a nuclear fuel reprocessing center from 1966 to 1972. During that time, approximately 640 metric tons of spent reactor fuel was processed. The plant accepted radioactive waste for disposal until 1975. Highly radioactive liquid wastes were generated and stored in an underground waste tank. Fifteen acres were used for disposal of radioactive waste from commercial waste generators and another seven acre landfill was used to dispose of radioactive waste generated from reprocessing.

The WNYNSC encompasses 14 square kilometers (5 square miles) in the town of Ashford, New York, in rural Cattaraugus County, approximately 50 kilometers (30 miles) southeast of Buffalo, New York. The West Valley Demonstration Project (WVDP) is located on approximately 80 hectares (200 acres) within the WNYNSC. The Project includes the former NFS plant and related facilities. Several additional facilities were constructed to complete the WVDP mission. In addition to the WVDP facilities, the WNYNSC includes two former radioactive disposal areas: an NRC-Licensed Disposal Area (NDA) within the Project premises, and State of New York-Licensed Disposal Area (SDA), which is not within the Project premises.

\section{OBJECTIVE}

The objective of the verification activities is to provide an independent review of the design, implementation, and performance of the radiological unrestricted release program for personal property, materials, and equipment (non-real property).

\section{VERIFICATION ACTIVITIES}

ORISE verification activities are summarized as follows:

\begin{tabular}{|l|l|l||}
\hline $\begin{array}{c}\text { Radiological Release } \\
\text { Program Aspect }\end{array}$ & ORISE Verification Activity & Evaluation Criteria \\
\hline \hline Program Design & $\begin{array}{l}\text { Document reviews of contractor } \\
\text { technical basis documents and } \\
\text { procedures. }\end{array}$ & $\begin{array}{l}\text { Regulatory requirements } \\
\text { specified below), } \\
\text { Best management practices, } \\
\text { Technical accuracy. }\end{array}$ \\
\hline
\end{tabular}




\begin{tabular}{|l|l|l||}
\hline $\begin{array}{c}\text { Radiological Release } \\
\text { Program Aspect }\end{array}$ & \multicolumn{1}{|c||}{ ORISE Verification Activity } & \multicolumn{1}{|c|}{ Evaluation Criteria } \\
\hline $\begin{array}{l}\text { Review of contractor survey and } \\
\text { training records, in-process } \\
\text { observation of contractor work } \\
\text { Implementation } \\
\text { practices and release activities, site } \\
\text { contractor and DOE staff. }\end{array}$ & $\begin{array}{l}\text { Compliance with site } \\
\text { procedures. }\end{array}$ \\
\hline Program Performance & $\begin{array}{l}\text { Independent measurement by ORISE } \\
\text { staff of selected items and/or } \\
\text { equipment released by the contractor. }\end{array}$ & $\begin{array}{l}\text { Residual contamination is below } \\
\text { release limits. }\end{array}$ \\
\hline \hline
\end{tabular}

\section{Program Review}

Document reviews were primarily conducted remotely with documents provided to ORISE by contractor and/or DOE staff. ORISE reviewed all pertinent program documents such as policies, procedures, and technical basis documents. These documents were evaluated against the requirements set forth in:

- 10 CFR 835, Occupational Radiation Protection, regarding release to a controlled area,

- DOE Order 5400.5, Radiation Protection of the Public and the Environment, Change 2 (DOE 1993), regarding release from a controlled area, and

- The clarification on the application of DOE Order 5400.5 sent via memorandum from Raymond Pelletier, Director of the DOE Office of Environmental Policy and Assistance (DOE 1995), regarding release limits for transuranics and tritium.

Additionally, the radiological unrestricted release program was evaluated against contractor internal requirements (e.g. procedural requirements), industry standards, best management practices, DOE implementation guidance, and for technical accuracy.

Applicable standards and implementation guidance documents include:

- ANSI N42.17A-1989, Performance Specifications for Health Physics Instrumentation - Portable Instrumentation for Use in Normal Environmental Conditions,

- ANSI N323A-1997, Radiation Protection Instrumentation Test and Calibration, Portable Survey Instruments, 
- ISO 7503-1, Evaluation of Surface Contamination Part 1 - Beta Emitters and Alpha Emitters,

- DOE G 441.1-1B, Radiation Protection Programs Guide for Use with Title 10, Code of Federal Regulations, Part 835, Occupational Radiation Protection,

- DRAFT - DOE G 441.1-XX, Control and Release of Property with Residual Radioactive Material, for use with DOE 5400.5, Radiation Protection of the Public and Environment., and

- DOE-STD-1098-99, Radiological Control.

\section{PROCEDURES}

Verification survey procedures included surface scans, direct measurements, and sampling for removable activity. Surveys were performed in accordance with a project-specific plan and the Independent Environmental Assessment and Verification (IEAV) Program's Survey Procedures and Quality Program Manuals (ORISE 2008a, 2008b, and ORAU 2007).

\section{Surface ACTivity MeAsurements}

Alpha and beta surface scans were performed on each of the items verified. For small items, 100\% of the item surface was surveyed. For large items, surveys covered a representative portion of the item, with particular attention given to cracks, joints, and other areas with higher potential for contamination. Surface scans were performed using Geiger-Mueller (Eberline Model HP-260) and zinc-sulfide scintillation (Eberline Model AC-3) detectors coupled to ratemeter-scalers (Ludlum Model 2221) with audible indicators. Smear samples were collected from representative locations of each item surveyed (or from selected items in a batch) to determine removable gross alpha and gross beta activity levels. Direct (static) measurements were to be performed on any areas of elevated radiation levels identified during scans, however no such elevated levels were identified during the ORISE visits.

\section{SAMPLE ANALYSIS AND DATA INTERPRETATION}

All data collected onsite were brought back to the ORISE facility for analysis and interpretation. Samples collected for radiological analysis were delivered to the ORISE radiochemistry laboratory in Oak Ridge, Tennessee for analysis. Sample analyses were performed in accordance with the IEAV Laboratory Procedures Manual (ORISE 2009). Smear samples were analyzed using a lowbackground proportional counter. Smear sample results are reported in units of disintegrations per minute per one-hundred square centimeters $\left(\mathrm{dpm} / 100 \mathrm{~cm}^{2}\right)$.

\section{GUIDELINES}

Based on past operations involving reprocessing of spent nuclear fuel, a variety of radiological contaminants are of potential concern at WVDP, including beta-gamma emitters (fission and activation products), and alpha-emitters (isotopes of uranium and transuranics). The release limits for surface contamination as promulgated in DOE Order 5400.5 are provided in Table 1 (DOE 1993). 


\section{FINDINGS AND RESULTS}

The ORISE review of the technical and programmatic aspects of the contractor's non-real property radiological release program found the program to generally be robust, well designed, and well implemented. Of special note were the technical basis documents and implementing procedures, as well as the dedicated staff. Two technical issues were noted during the first ORISE visit (June 2008). These issues were:

1) An inconsistency between procedures and the technical basis regarding calibration with a 4-pi methodology versus a 2-pi emission rate methodology from ISO-7503-1.

2) Potential ingrowth of Am-241 as a contaminant in the Pu-239 calibration sources.

These two issues are described in detail in the ORISE trip summary report (ORISE 2008c), and were resolved prior to issuance of this report. There are no unresolved technical issues noted by the ORISE verification.

Alpha and beta scanning survey measurements of previously released items and equipment indicated no direct radiation levels distinguishable from background, and therefore no contamination exceeding the release criteria. All smear results were also less than the removable activity release criteria. Instrument scan and smear results are summarized in Table 2.

\section{Comparison of SCAN SURVEYS AND SMEARS AgAinst THE RELEASE Criteria}

Groups 1 and 4 in Table 1, transcribed from DOE Order 5400.5 (DOE 1993), were used as release criteria due to the history of the WVDP site. The "Average" limits were used as the default limits during scans and for smears. A $1 \mathrm{~m}^{2}$ area-averaged limit would apply to contaminated areas larger than $100 \mathrm{~cm}^{2}$, however no such areas were found during the ORISE visits. 
Table 1: Allowable Total Residual Surface Activity $\left(\mathrm{dpm} / 100 \mathrm{~cm}^{2}\right)^{1}$

\begin{tabular}{||l|c|c|c||}
\hline \multicolumn{1}{|c|}{ Radionuclides $^{2}$} & Average $^{3,4}$ & Maximum $^{5,6}$ & Removable $^{7}$ \\
\hline \hline $\begin{array}{l}\text { Group 1 - Transuranics, I-125, I-129, Ac-227, } \\
\text { Ra -226, Ra-228, Th-228, Th-230, Pa-231 }\end{array}$ & 100 & 300 & 20 \\
\hline $\begin{array}{l}\text { Group 2 - Th-natural, Sr-90, I-126, I-131, I-133, Ra-223, } \\
\text { Ra-224, U-232, Th-232 }\end{array}$ & 1,000 & 3,000 & 200 \\
\hline $\begin{array}{l}\text { Group 3 - U-natural, U-235, U-238, and associated } \\
\text { decay products, alpha emitters }\end{array}$ & 5,000 & 15,000 & 1,000 \\
\hline $\begin{array}{l}\text { Group 4 - Beta-gamma emitters (radionuclides with } \\
\text { decay modes other than alpha emission or spontaneous } \\
\text { fission }\end{array}$ ) except Sr-90 and others noted above & 5,000 & 15,000 & 1,000 \\
\hline Tritium (applicable to surface and subsurface) & $\mathrm{N} / \mathrm{A}$ & $\mathrm{N} / \mathrm{A}$ & 10,000 \\
\hline
\end{tabular}

\footnotetext{
${ }^{1}$ As used in this table, dpm (disintegrations per minute) means the rate of emission by radioactive material as determined by counts per minute measured by an appropriate detector for background, efficiency, and geometric factors associated with the instrumentation.

${ }^{2}$ Where surface contamination by both alpha- and beta-gamma-emitting radionuclides exists, the limits established for alpha- and beta-gamma-emitting radionuclides should apply independently.

${ }^{3}$ Measurements of average contamination should not be averaged over an area of more than $1 \mathrm{~m}^{2}$. For objects of smaller surface area, the average should be derived for each such object.

${ }^{4}$ The average and maximum dose rates associated with surface contamination resulting from beta-gamma emitters should not exceed $0.2 \mathrm{mrad} / \mathrm{h}$ and $1.0 \mathrm{mrad} / \mathrm{h}$, respectively, at $1 \mathrm{~cm}$.

${ }^{5}$ The maximum contamination level applies to an area of not more than $100 \mathrm{~cm}^{2}$.

${ }^{6}$ The amount of removable material per $100 \mathrm{~cm}^{2}$ of surface area should be determined by wiping an area of that size with dry filter or soft absorbent paper, applying moderate pressure, and measuring the amount of radioactive material on the wiping with an appropriate instrument of known efficiency. When removable contamination on objects of surface area less than $100 \mathrm{~cm}^{2}$ is determined, the activity per unit area should be based on the actual area and the entire surface should be wiped. It is not necessary to use wiping techniques to measure removable contamination levels if direct scan surveys indicate that the total residual surface contamination levels are within the limits for removable contamination. ${ }^{7}$ This category of radionuclides includes mixed fission products, including the Sr-90 which is present in them. It does not apply to Sr-90 which has been separated from the other fission products or mixtures where the Sr-90 has been enriched.

${ }^{8}$ Property recently exposed or decontaminated should have measurements (smears) at regular time intervals to ensure that there is not a build-up of contamination over time. Because tritium typically penetrates material it contacts, the surface guidelines in group 4 are not applicable to tritium.
} 


\begin{tabular}{|c|c|c|c|c|c|}
\hline \multicolumn{6}{|c|}{$\begin{array}{c}\text { TABLE 2: RADIOLOGICALLY RELEASED ITEM } \\
\text { SURFACE ACTIVITY LEVELS } \\
\text { WEST VALLEY DEMONSTATION PROJECT } \\
\text { ASHFORD, NEW YORK }\end{array}$} \\
\hline \multirow[t]{2}{*}{ Item } & \multicolumn{2}{|c|}{$\begin{array}{l}\text { Activity by Scan } \\
\left(\mathrm{dpm} / 100 \mathrm{~cm}^{2}\right)\end{array}$} & \multirow{2}{*}{$\begin{array}{l}\text { ORISE Smear } \\
\text { Number }\end{array}$} & \multicolumn{2}{|c|}{$\begin{array}{c}\text { Removable } \\
\text { Activity }^{\mathrm{b}} \\
\left(\mathrm{dpm} / 100 \mathrm{~cm}^{2}\right)\end{array}$} \\
\hline & Alpha & Beta & & Alpha & Beta \\
\hline \multirow{5}{*}{ Roll-up Door } & \multirow{5}{*}{$\mathrm{ND}^{\mathrm{a}}$} & \multirow{5}{*}{ ND } & 1 & 3 & -1 \\
\hline & & & 2 & 1 & -1 \\
\hline & & & 3 & 0 & -3 \\
\hline & & & 4 & 1 & 3 \\
\hline & & & 5 & 0 & -2 \\
\hline \multirow{5}{*}{ Shed T-ST-56 } & \multirow{5}{*}{$\mathrm{ND}$} & \multirow{5}{*}{ ND } & 6 & 3 & -6 \\
\hline & & & 7 & 0 & 1 \\
\hline & & & 8 & 0 & -1 \\
\hline & & & 9 & 1 & -2 \\
\hline & & & 10 & 0 & -3 \\
\hline \multirow{5}{*}{ Electrical Transformer } & \multirow{5}{*}{ ND } & \multirow{5}{*}{ ND } & 11 & 1 & -3 \\
\hline & & & 12 & 0 & -2 \\
\hline & & & 13 & 3 & -1 \\
\hline & & & 14 & 0 & 1 \\
\hline & & & 15 & 0 & -3 \\
\hline \multirow{3}{*}{ Fall Protection Harness } & \multirow{3}{*}{ ND } & \multirow{3}{*}{ ND } & 16 & 2 & -2 \\
\hline & & & 17 & 0 & -1 \\
\hline & & & 18 & 2 & 3 \\
\hline \multirow{14}{*}{ Spare Tenelec Parts } & \multirow{14}{*}{ ND } & \multirow{14}{*}{ ND } & 19 & 0 & 3 \\
\hline & & & 20 & 0 & 1 \\
\hline & & & 21 & 0 & -2 \\
\hline & & & 22 & 0 & 2 \\
\hline & & & 23 & 2 & 2 \\
\hline & & & 24 & 0 & -1 \\
\hline & & & 25 & 0 & -2 \\
\hline & & & 26 & 0 & 2 \\
\hline & & & 27 & 0 & 1 \\
\hline & & & 28 & 0 & 2 \\
\hline & & & 29 & 0 & -4 \\
\hline & & & 30 & 0 & -2 \\
\hline & & & 31 & 0 & -1 \\
\hline & & & 32 & 0 & -2 \\
\hline
\end{tabular}




\begin{tabular}{|c|c|c|c|c|c|}
\hline \multicolumn{6}{|c|}{$\begin{array}{l}\text { TABLE 2: RADIOLOGICALLY RELEASED ITEM (Con't.) } \\
\text { SURFACE ACTIVITY LEVELS } \\
\text { WEST VALLEY DEMONSTATION PROJECT } \\
\text { ASHFORD, NEW YORK }\end{array}$} \\
\hline \multirow[t]{2}{*}{ Item } & \multicolumn{2}{|c|}{$\begin{array}{l}\text { Activity by Scan } \\
\left(\mathrm{dpm} / 100 \mathrm{~cm}^{2}\right)\end{array}$} & \multirow[t]{2}{*}{$\begin{array}{l}\text { ORISE Smear } \\
\text { Number }\end{array}$} & \multicolumn{2}{|c|}{$\begin{array}{l}\text { Removable } \\
\text { Activity }^{\mathrm{b}} \\
\left(\mathrm{dpm} / 100 \mathrm{~cm}^{2}\right)\end{array}$} \\
\hline & Alpha & Beta & & Alpha & Beta \\
\hline \multirow{3}{*}{ Asbestos Sample Cartridges } & \multirow{3}{*}{ ND } & \multirow{3}{*}{ ND } & 33 & 0 & -3 \\
\hline & & & 34 & 0 & 4 \\
\hline & & & 35 & 0 & -2 \\
\hline \multirow{3}{*}{$\begin{array}{l}\text { Breathing Zone Air Samplers } \\
\text { (BZASs) }\end{array}$} & \multirow{3}{*}{ ND } & \multirow{3}{*}{ ND } & 36 & 0 & 1 \\
\hline & & & 37 & 0 & 1 \\
\hline & & & 38 & 2 & 6 \\
\hline \multirow{2}{*}{$\begin{array}{l}\text { Powered Air-Purifying Respirators } \\
\text { (PAPRs) }\end{array}$} & \multirow{2}{*}{ ND } & \multirow{2}{*}{ ND } & 39 & 0 & -2 \\
\hline & & & 40 & 0 & 1 \\
\hline \multirow{10}{*}{ Containment Curtain \#1 } & \multirow{10}{*}{ ND } & \multirow{10}{*}{ ND } & 41 & 0 & 1 \\
\hline & & & 42 & 0 & -2 \\
\hline & & & 43 & 2 & -2 \\
\hline & & & 44 & 2 & -2 \\
\hline & & & 45 & 0 & -1 \\
\hline & & & 46 & 0 & -4 \\
\hline & & & 47 & 0 & -5 \\
\hline & & & 48 & 2 & -3 \\
\hline & & & 49 & 0 & 1 \\
\hline & & & 50 & 0 & 6 \\
\hline \multirow{10}{*}{ Containment Curtain \#2 } & \multirow{10}{*}{ ND } & \multirow{10}{*}{ ND } & 51 & 0 & -1 \\
\hline & & & 52 & 2 & -2 \\
\hline & & & 53 & 0 & 2 \\
\hline & & & 54 & 0 & 1 \\
\hline & & & 55 & 0 & -2 \\
\hline & & & 56 & 2 & -4 \\
\hline & & & 57 & 0 & -3 \\
\hline & & & 58 & 0 & 2 \\
\hline & & & 59 & 0 & 3 \\
\hline & & & 60 & 0 & 1 \\
\hline \multirow{3}{*}{ Dynamometer } & \multirow{3}{*}{ ND } & \multirow{3}{*}{ ND } & 61 & 0 & 4 \\
\hline & & & 62 & 0 & 2 \\
\hline & & & 63 & 0 & -4 \\
\hline
\end{tabular}

aA scan result of "ND" indicates "None Detected", meaning that no instrument response above background levels was detected.

bMinimum Detectable Concentration (MDC) for the measurement method for smears was no higher than $11 \mathrm{dpm} / 100 \mathrm{~cm}^{2}$ for alpha radiation and 15 $\mathrm{dpm} / 100 \mathrm{~cm}^{2}$ for beta radiation. 


\section{REFERENCES}

Oak Ridge Associated Universities (ORAU). Quality Program for the Independent Environmental Assessment and Verification Program. Oak Ridge, TN; November 1, 2007.

Oak Ridge Institute for Science and Education (ORISE). Project Specific Plan for Independent Verification of the Non-Real Property Radiological Unrestricted Release Program at the West Valley Demonstration Project, West Valley, New York. DCN: 0488-PL-01-0. Oak Ridge, TN; April 30, 2008a.

Oak Ridge Institute for Science and Education. Survey Procedures Manual for the Independent Environmental Assessment and Verification Program. Oak Ridge, TN; May 1, 2008b.

Oak Ridge Institute for Science and Education. Interim Letter Report Revision 1: ORISE Independent Verification of the West Valley Demonstration Project Non-Real Property Radiological Release Program, Summary of Activities for the Onsite Visit of June 10-12, 2008.

DCN: 0488-TR-01-1. Oak Ridge, TN; June 24, 2008c.

Oak Ridge Institute for Science and Education. Laboratory Procedures Manual for the Independent Environmental Assessment and Verification Program. Oak Ridge, TN; March 3, 2009.

U.S. Department of Energy (DOE). DOE Order 5400.5, Radiation Protection of the Public and Environment. Washington, D.C.; January 1993.

U.S. Department of Energy. Memorandum from Raymond Pelletier, Director, Office of Environmental Policy and Assistance, regarding application of DOE O 5400.5 requirements for release and control of property containing residual radioactive material. Washington, D.C.; November 1995. 